\title{
Reimagining the History of the Avant-garde: Photography and the Journal Sovetskoe foto in the 1950 and Early 1960 s
}

\author{
Jessica Werneke \\ NRU Higher School of Economics \\ Myasnitskaya ul., 20, Moscow, Russia, 101000 \\ jessicawerneke@yahoo.com
}

Nikita Khrushchev's 1956 speech "On the Cult of Personality and its Consequences," delivered at the Twentieth Party Congress, sent shock waves through the Soviet intellectual, political, and cultural community. The period that followed, known as the Thaw, a term drawn from Ilya Eherenberg's 1954 novel of the same title, brought sweeping socio-political reform and a reorientation of Soviet society and the relationship between the Soviet government and its citizens.

This article addresses how the cultural Thaw provided the backdrop necessary for photographers to reinvestigate the creative possibilities of photography. I argue that rather than putting a decisive end to avant-garde techniques, the Stalinist period only temporarily quietened these debates, which reemerged amongst photographers and photography critics in the mid-1950s. ${ }^{1}$ The discourse surrounding Soviet photography in the 1950s and 196os attempted to determine photography's role in the post-Stalinist epoch. The expression of that role, of photography as artistic and documentary, normalized avant-garde aesthetics in Thaw era press photography. The manifestation of these new (or rather, old) creative and expressive

1 Masha Chlenova has demonstrated that despite the "totalitarian model" which focuses on how terror and repression silenced debates about avant-garde art, the installation of socialist realism and the demise of the avant-garde was far more complex. Instead, both were "negotiated in practice through display and debate" and that socialist realism "de facto came to be recognized as a necessary style for the construction of a socialist society, while avant-garde strategies came to be seen as outdated." In photography, however, Thaw era socialist realism in photography came to incorporate less radical aspects of avant-garde focus and angular composition. Masha Chlenova, On Display: Transformations of the Avant-Garde in Soviet Public Culture, 1928-1933, PhD diss. Columbia University, 2010, 17. 
elements of photojournalism derived from reimagining, repurposing, and reinvestigating various avant-garde techniques while simultaneously questioning the relationship between the photograph's artistic and journalistic properties. The relative openness of this period offered a forum in which photojournalists could discuss their craft and re-conceptualize their work in ways that had been impossible in previous decades. Soviet photographers who worked for illustrated journals were able to challenge the notion that photography was simply a documentary or ideological tool. ${ }^{2}$ They promoted interest in photography, and advocated techniques that drew upon the avant-garde photography movements of the 1920s, emphasizing creativity and expressiveness in press photography. ${ }^{3}$

The late 1950s through the early 196os are commonly referred to as the Thaw or the cultural Thaw, terms that generally indicate the limited liberalization that occurred while Khrushchev was in power. Yet, as many scholars, including Polly Jones, have noted, "Observers of the 1950s and 196os, and today's many scholars of the period, have emphasized both the precarious balance of conservatism and liberalism and the succession of 'thaws' and 'freezes' that characterized Soviet state and society after Stalin's death." ${ }^{4}$ This was true of economic, social and cultural policy, as the Party and government wavered between advocates of reform and proponents of Stalinism who remained in power after his death. In terms of cultural policies, the Thaw has been described as a period of "hesitant yet pronounced changes to Stalinist totalitarianism" but also a time in which the main hallmarks of Stalinism, lack of "access to information and freedom of speech" remained. ${ }^{5}$ Other scholars have described the Khrushchev era as an age of anxiety, in which artists, writers, and the intelligentsia were wary of such sudden change in the wake of the Secret Speech. ${ }^{6}$ For photographers, particularly photojournalists, who were a part of the intelligentsia but remained squarely outside of established elitist artistic

2 Leah Dickerman. "Camera Obscura: Socialist Realism in the Shadow of Photography," October 93, no. 3 (2000): 143 .

3 See Masha Chlenova, On Display, 13-17.

4 Polly Jones, Review of 'Khrushchevskaia ottepel' $i$ obshchestvennye nastroeniia $v \operatorname{sssR} v$ 1953-1964 gg. and Kak eto delalos' $v$ Leningrade: Tsenzura $v$ gody ottepeli, zastoia i perestroika, 1953-1991,' Kritika, Vol. 8 No. 3, Summer 2007, 695.

5 Ibid, 695 .

6 Miriam Dobson, Khrushchev's Cold Summer: Gulag Returnees, Crime and the Fate of Reform After Stalin, (Ithaca: Cornell University Press, 2009), 15. Also see Stephen V. Bittner, The Many Lives of Khrushchev's Thaw: Experience and Memory in Moscow's Arbat, (Ithaca, NY: Cornell University Press, 2008), 9. 
institutions in the Soviet Union, the Thaw era was met with both opportunism and apprehension. ${ }^{7}$ As photographers sought to promote the artistic merits of their work through channeling aspects of the outcast avant-garde movements of the 1920s, they also approached the subject with caution, acknowledging the dual role of photography as both indexical and artistic.

Photographers and critics who attempted to revise Stalinist norms were not alone in their cause, yet their circumstances differed substantially from artists and writers who were part of established and insular unions. For example, writers during the cultural Thaw encountered not only the remaining institutional structures in place from the Stalinist epoch, but also ideology that was firmly embedded in "progress," Party unity, and access to contacts and personal connections for admission into the Writer's Union, publication, and notoriety. ${ }^{8}$ Photojournalists, many of whom came from the ranks of amateurs, or, alternatively, had participated in the avant-garde artists' groups of the 1920 and 1930 s themselves, were not necessarily a part of the official, or established socialist realist, art community. Some critics, such as Sergei A. Morozov, Leonid F. Volkov-Lannit, and critic-photographer Semyon Friedland contributed to purging the "bourgeoisie elements" in photography during Stalin's Cultural Revolution. ${ }^{9}$ In the 1950 os and 1960s, they continued to work as photographers and published about photography. Nevertheless, they participated in and supported broadening debates about avant-garde photographer's influence on photography into the 1950s and 196os. This further complicated the role of photography in the Thaw as a medium that operated not only between professional and pseudo-professional, acceptable versus unacceptable experimentation, but, unlike other media, occupied the uncertain terrain between art and journalism which critics and photographers freely admitted.10

7 Vladislav Zubok, Zhivago's Children: The Last Russian Intelligentsia, (Harvard University Press: Cambridge, MA, 2009), 22.

8 Polly Jones, "The Personal and the Political: Opposition to the Thaw and the Politics of Literary Identity in the 1950s and 196os." The Thaw: Soviet Society and Culture During the 1950s and 196os, eds. Denis Kozlov and Eleonory Gilburd 231-265, (University of Toronto Press: Toronto, 2013), 234.

9 Sergei Morozov, Fotoilliustratsiia v gazete, (Moskva: Goskinoizdat, 1939), 6.; Leonid VolkovLannit, O kompozitsii reportazhnogo fotoportreta (Moskva: Izdatelstvo Tsentral'nyi dom zhurnalista, 1962), 19.

10 Sergei Morozov, Sovetskaia khudozhestvennaya fotografia, (Moskva: Isskustvo, 1958), 123. Sovetskoe foto also contains many examples, including "Otosiudu' v fotosektsiiakh soiuza zhurnalistov," Sovetskoe foto, no. 7 (1961): 44. 
In the 1950s, photographers and photojournalists were wrestling with the possibilities of representing the new and challenging environment. As Susan Reid has noted, photography in the late 1950s and into the 1960s, and particularly the photograph's perceived "truth" and "authenticity," were galvanized as a means of exposing the fallacies of the Stalinist past. As a result, documentary reportage was privileged, but discussions surrounding the nature of photography and photographic realism also incorporated an "increasing emphasis on authorial engagement and the artist's individual, expressive and persuasive use of the medium."11 Working for various press agencies, ultimately these photojournalists and photography editors were responsible to and held accountable by the Central Committee and the Presidium. ${ }^{12}$ Nevertheless, the atmosphere of the Thaw allowed these photographers opportunities and the limited ability to dictate their own creative standards and choices, so long as they upheld the appearance of dedication to "truth" and their photographs did "not lapse into formalist, aesthetic ends in themselves."13

Sovetskoe foto (The Soviet Photograph), the premiere photography journal of the Soviet Union, was reestablished in 1956 and resumed publication in January of $1957 .{ }^{14}$ The first edition of the journal, intended as a monthly periodical for amateurs and photojournalists, was published by Ogonek in April 1926 and edited by Mikhail Koltsov and Viktor Petrovich Mikylin. The back cover of the first issue clearly stated the objectives of the editors and the contents of the journal. Sovetskoe foto would address the problems of Soviet photography, questions about photographic equipment, the basic composition of pictures, how to photograph for magazines and newspapers, and would include sections for frequently asked questions, reviews of reader's pictures and tips for beginners. ${ }^{15}$ Photojournalism was not only historically

11 Susan E. Reid, "Photography in the Thaw." Art Journal 53, no. 2, (1994): 33.

12 "O ser'eznykh nedostatkakh v soderzhanii zhurnala Ogonek," 9 September 1958 (RGANI f. 11, op. 1, d. 20, 1. 2). The Central Committee's stance towards photography, as opposed to that of the editors of Sovetskoe foto, was illustrated in the March 1957 issue of the journal, which outlined the proceedings of the All-Union Congress of Soviet Artists. Photography was not mentioned once in the article, and yet, the decision to print the article prominently in the first pages of the journal demonstrates that the editorial staff felt that it was of relevance to the work of photojournalists and amateur photographers. "Privetstvie TsK KPSS vsesoiuznomu s'ezdu sovetskikh khudozhnikov," Sovetskoe foto, no. 3 (1957): 1-2.

13 Susan E. Reid, "Photography in the Thaw," 34.

14 The journal was first established in 1926 by Mikhail Koltsov, and its first issue was published in April of that year. The journal ceased publication in 1941 before it was reestablished in 1956.

15 Sovetskoe foto, no. 1 (1926): Back Cover. 
important, but also allowed citizens the opportunity to "learn the truth about the changes occurring" under the Bolshevik regime. These changes needed to be documented because "everyday moments reveal a fuller and deeper meaning in life."16 Photography's perceived "truthfulness" and connection to depicting reality remained a politically and ideologically convenient means of describing the medium in the post-Stalinist period, expunging the excesses of the past. ${ }^{17}$

After 1956 Sovetskoe foto was published by Iskusstvo (Art), one of the publishing houses of the Ministry of Culture and became the primary setting for photographers and photojournalists to view and discuss each other's work. From January 1957 to December 1959, the journal was published monthly on newspaper stock, featuring predominantly black-and-white images, and each issue was approximately sixty pages long. Beginning in January 1960, and for the remainder of the Soviet period, the front and back covers, as well as color inserts, of Sovetskoe foto were printed on glossy paper stock. As of the first edition of 1960, the journal itself was printed on larger paper as well, cutting the number of pages to approximately fifty per issue.

Many photographers found the reestablishment of a journal devoted specifically to all aspects of photography as a step in the right direction for incorporating photography into established professional and artistic cultural institutions. Sovetskoe foto provided a forum for photographers and photojournalists to grapple with the nature of post-Stalinist documentary and aesthetic representation. In particular, the apparent shift, or lack thereof, in photographic aesthetics allowed for the reevaluation of the relationship between photography, art, and journalism. In the ambiguous climate surrounding Khrushchev's cultural Thaw, photojournalists sought to define the photograph's relationship to journalism and art in various ways, sometimes with uncertainty, but more frequently with the conviction that photography was as much an artistic form as it was a documentary medium.

In the November 1964 issue of Sovetskoe foto, L. Filipov described the role of the accomplished Soviet photojournalist:

The talented artist moves creativity forward, is lit by the great ideas of a century, and is inspired by the noble mission of service to the people... There is no art outside of time even if it chooses a theme in the past... The mighty force of a photograph, the truth is seen in its conclusive

16 Ibid, 18.

17 Susan E. Reid, "Photography in the Thaw." 33-4. 
reliability, in the incontestable persuasiveness of its documentary certification. Documentation does not exclude artistry. ${ }^{18}$

Ideologues and professionals pulled from the ranks of photojournalists had concrete goals that required photographers to become more than mere recorders of 'facts' or occurrences. ${ }^{19}$ Filipov's statement, the first words of the first paragraph found in this issue of Sovetskoe foto, suggests that the Soviet photojournalist had two very different obligations to fulfill. The first was to present images that provided indexical evidence of technological and other advances made in the Soviet Union, to supply a visual fact that could support the rhetoric of Soviet state building. The second, more ambiguous obligation was to produce pictures that upheld high aesthetic standards. As this article demonstrates, Sovetskoe foto required more than mere documentation from its photographers. Consistently, articles supporting, evaluating, and debating the cultural role of the photojournalist and art photography can be found in virtually every issue of Sovetskoe foto from the late 1950s through the 196os. A clear consensus appears to have been reached: the standard for creating a professional photographic image was that it fulfilled the role of document and artistic object simultaneously.

This was no easy task. Years earlier, in the 1920s and 1930s, photographers struggled to define the relationship between the photographer as an artist and the photographer as a journalist, and likewise the relationship between photography, art and journalism. Photographers and critics like Sergei Morozov were no clearer about the definitions of art photography and photojournalism in the 1950s and 196os. In 1958, Sergei Morozov's Sovetskaia khudozhestvennaya fotografiia (Soviet Artistic Photography) highlighted the role of photography as a creative (though not necessarily inherently artistic) media that was bound to journalism. "Photography developed in close proximity with the periodical press in the Soviet Union," Morozov wrote, “...largely, communication with the press determines the strength of Soviet artistic photography."20 Yet, Morozov abstains from awarding photography official artistic status. "This book does not deal with the theoretical position of photography as art...suffice it to say that life experience confirms that photographs provide aesthetic pleasure to many thousands of enthusiasts, and dozens of images are unanimously recognized

\footnotetext{
18 L. Filipov, “Rodilsia v oktiabre," Sovetskoe foto, no. 11 (1964): 1.

19 M. Bugayeva, "O printsipi partiinost' v fotoiskusstva," Sovetskoe foto, no. 2 (1961): 1-2.; "Dlia verkhovnogo ideologicheskoi fotozhurnalistiki," Sovetskoe foto, no. 3 (1961): 1.; A. Zis, "C khudozhnika sprositsia," Sovetskoe foto, no. 8 (1960): 17.

20 Sergei Morozov, Sovetskaia khudozhestvennaya fotografiia, 5 .
} 
as art."21 Morozov questions the ability of photography to create "the sum of all reality," the purpose of Soviet art as he interprets it from Maxim Gorky's speech at the First All-Union Congress of Writers in 1934. Yet, he also points to the stylistic and creative differences in the photographs of contemporary photographers, such as Yuri Ermin, and Aleksandr Shterenberg, and that "unique individual characteristics of contemporary photographers" was "strong evidence of the creative freedom of photography" and "mark the stylistic features of art."22 Despite these artistic features and creative abilities, it would appear that from a theoretical standpoint, Morozov could not justify art photography in socialist realist terms: while artistic and documentary, photography at least until the 1950s, had failed to provide the totality or "sum of reality" required of Soviet art. The word fotoiskusstvo itself defies any certain definition. While the literal translation is "photographic art," its usage is flexible and liberally applied to both documentary images and exhibition 'art objects' in Sovetskoe foto. More frequently, however, photography was referred to as "aesthetic" or "artistic," as an adjective (esteticheskaia fotografiia or khudozhestvennaia fotografia) rather than noun (fotoiskusstvo). This emphasizes artistry as an aspect of particular photographs rather than inherent to the medium or one particular photographer.

The connections between artistry and journalism were further explored by critic and photographer Leonid Volkov-Lannit. "Every artistic picture," wrote Volkov-Lannit, in 1962, "is the result of the author's relationship to the depicted events." In photography, "realism partnered with art obliges every photographer to relentlessly pursue innovation in searching for the most expressive techniques." In this way, Volkov-Lannit explains that successful Soviet photographs merged the artistic, creative, and documentary aspects of photography in a single image. ${ }^{23}$ Furthermore, as historian of Soviet photography V.T. Stigneev points out, in the "controversy and debate about the nature of photographic reporting, the artistic quality of the image was not a distraction from the photographic practice, however... it affected its assessment and, therefore, the specific job of photojournalists." 24 In a rather round-about way, Stigneev is referring to the debate surrounding the express purpose of photography in journalism and in art. It was generally accepted by newspaper and journal editors at the time that artistry in press photographs did not detract from an image's ability to

\footnotetext{
$21 \quad$ Ibid, 272.

22 Ibid, 272-3.

23 Leonid Volkov-Lannit, O kompozitsii reportazhnogo fotoportreta, 21.

24 V.T. Stigneev, Vek Fotografii: ocherkii istorii otechestvennoi fotografii 1894-1994, (Moskva: Knizhni Dom 'Lıввоком', 2009), 220.
} 
effectively illustrate news topics. Similarly, editors recognized that debate about the aesthetics of news photography, between photographers themselves and press employees, improved the final product. But debates about the role of artistry in photojournalism influenced choices about which images were publishable, how they were critiqued (in particular by contributors to Sovetskoe foto), and therefore, what was required of the photojournalist. These requirements were largely fluid and changed from publication to publication, and from year to year. Further complicating the role of aesthetics in photography and journalism is that any critique of artistic or journalistic photographs was steeped in the critical language used in appraising literature and painting, which was not always relevant or appropriate. ${ }^{25}$ As seen above, contemporary critics found it difficult to place photography within the theoretical boundaries of socialist realist art, because the very nature of photography as perceived by Soviet critics (as documentary, based in reality) conflicted with the express purpose of socialist realism's theoretical totality, which, whether acknowledged or not, by definition blurred the lines between reality and fiction. ${ }^{26}$ By the 196os, the stock declarations of photography having achieved the status of other artistic media were common place in illustrated journals, particularly Sovetskoe foto. Yet publications and articles about photography theory (even in Sovetskoe foto) carefully side-stepped these declarations, stating merely that photography contained many of the creative and aesthetic qualities of socialist realist art. ${ }^{27}$ The "confident and self-congratulatory declarations barely reached the ears of the elitist Soviet art establishment, for they were made in the quite separate context of the profession of journalism" and not in the context of photography as "high" art. ${ }^{28}$

By 1937, according to art historian Margarita Tupitsyn, Constructivism and Productivism were overtaken by socialist realism. ${ }^{29}$ Photography's truthfulness was perceived as unreliable in depicting the teleological and historical

$25 \quad$ Ibid, 221.

26 Evgeny Dobrenko, Political Economy of Socialist Realism, (New Haven: Yale University Press, 2007), 183 .

27 In 1968 Sovetskoe foto published a year-long series of articles debating the role of art and photography, though the author, M. Kagin, failed to reach a definitive conclusion in that time. He instead pointed to the "artistic" and "creative" features of photography, which made it unique amongst artistic media. M. Kagin, "Soderzhanie i forma v proizvedeniiakh fotoiskusstva," Sovetskoe foto, no. 5 (1968): 27.

28 Susan E. Reid, "Photography in the Thaw," 36.

29 Margarita Tupitsyn, The Soviet Photograph 1924-1937, (New Haven: Yale University Press, 1996). 
narrative that the Party and government put forth. Photography, precisely because of its documentary features and the photograph's apparent inability to lie, or show what was and was not in front of it, made it a liability. ${ }^{30}$ The 1930 s and 1940s saw the gradual replacement of modernism with realism, though not documentary realism, in all Soviet arts. When possible, journals replaced photographs with socialist realist paintings and other forms of representation from the mid-1930s until the second Word War, a process that continued from 1945 into the early 1950s. ${ }^{31}$ The distinction between art photography and press photography remained ill defined, and the lines between the two genres were blurred in the 1920 s and 1930 s by years of debate about what acceptable photographs should look like. While early discussions about photography in avant-garde circles included Osip Brik's assertion that photography replaced the need for other visual forms, notably painting, much of the material published in Sovetskoe foto during the 1920 and 1930 s reflected the tensions between the Union of Russian Proletarian Photographers (ROPF) and the Oktiabr photography circles. ${ }^{32}$ The latter was led largely by Aleksandr Rodchenko in matters of photography, but Gustav Klutsis, Elizar Langman, Dmitri Debabov, and Boris Ignatovich all identified with the group. The ROPF was spearheaded by Leonid Mezhericher, Arkadii Shaikhet, Semyon Friedland and Maks Alpert and favored "straightforward, supposedly unmanipulated reportage" but also had aesthetic aspirations. ${ }^{33}$ Though both groups were committed to documentary representation, they differed in their methodological approach to documentary composition. The work of Oktiabr was based "on fragmentation

$30 \quad$ Leah Dickerman. "Camera Obscura," 143. Also see David King, The Commissar Vanishes: The Falsification of Photographs and Art in Stalin's Russia, (New York: Metropolitan Books, 1997).

31 Though photography played an important documentary role in illustrating Soviet involvement in World War II, many subjects were strictly off limits and photographers received pre-assigned subjects from editors before reaching the front. As a result, this "documentary footage" was already hemmed in by editorial and state directives before photographers shot their photographs. V.T. Stigneev, Vek Fotographii: Ocherki Ictorii Otechestvennoi Fotografii 1894-1994, (Moskva: Knizhni Dom Liвroком, 2011), 145. Additionally, in the 1970s, Dimitri Baltermants, as head of the Photography Section of Ogonek, commented that "If I ever again had to photograph the war, I would have shot it completely differently," implying that he may have ignored contemporary editorial demands. D. Baltermants, Fotografiia, no. 2 (1972): 19.

32 O. Brik, "Foto-kadr protiv kartiny," Sovetskoe foto, no. 2 (1926): 40.; S. Evgenov, "Po stranitsam Sovetskoe foto: Ranie snimki 1926-1928," Sovetskoe foto, no. 4 (1941): 9.

33 Leah Bendavid-Val, Propaganda and Dreams: Photographing the 1930s in the UssR and the us, (Zurich; Edition Stemmle, 1999), 37. 
and they viewed reality as a disconnected and puzzling space" while the ROPF "leaned toward whole images and saw the world as a concrete and continuous entity." ${ }^{34}$ To the ROPF, members of Oktiabr were more interested in innovation than documentation. Oktiabr itself was established based on the premise that its members "felt that the new era required new media and as yet untried processes and they wanted to apply mass production to art." Part of this experimentation "involved the tearing down of walls between media, so that one artist could learn from another." ${ }^{35}$ Years later, when asked about Oktiabr, photographer Mark Markov-Grinberg (who identified with the ROPF) stated that though he admired Rodchenko's initiative and innovative style, he did not care for the stylized approach taken by other members of the group: "Usually their strange angles did not appeal to us realists; how can you walk on a diagonal horizon? You'd have to be a mountain climber." ${ }^{36}$ Generally, though, aesthetic differences between the two groups stemmed from fundamentally different ideas about the purpose of the camera. Markov-Grinberg's main objection to Oktiabr was that form and style overtook content in their photographs. "Chasing after the shot dominated content," he said. "We, in the opposite group, photographed for a reason, for a purpose. Art for art's sake is nothing. But still, initially Rodchenko was our teacher and we were friends." ${ }^{37}$ These debates were cut short when the Soviet government forced the liquidation of avant-garde photography groups, silencing public disagreements about photographic techniques such as abstraction, unique angles, and intense cropping. ${ }^{38}$ By the 1950 s, these debates resurfaced, focusing on the creative possibilities of photojournalism.

34 Margarita Tupitsyn, The Soviet Photograph, 67.

35 Ibid, 67.

36 Leah Bendavid-Val, Propaganda and Dreams, $36-7$.

37 Ibid, 37 .

38 Following the consolidation of artistic groups, in $1932 \mathrm{Oktiabr}$ began a restructuring process that aligned its work more closely with that of the ROPF. Rodchenko, however, refused to cooperate. "In light of his systematic refusal to participate in the restructuring practice and repeated claims of reluctance to engage in this reconstruction," the new chairman of Oktiabr, Boris Ignatovich, formally expelled Rodchenko, revoking his membership. In the following months, the ROPF dissolved the extraneous departments of Oktiabr, and the groups merged, becoming the Creative Union of Press Workers. This publicly concealed the continued artistic disagreements between the two groups. Later in 1932 the ROPF and Oktiabr were disbanded in name, though the members of both groups continued to exhibit their work alongside one another until the 1935 Exhibition of the Masters of Soviet Photography (though the latter's work had been denounced as formalist). The forced liquidation and subsequent presentation of Soviet photographers as an aesthetically united entity 
The theoretical debates about Soviet photography and photojournalism in the 1950 s and 196os focused on two main ideas that were linked to one another. The first focused on the purpose of photography and its relations to realism and to journalism. Photography in the Soviet Union should be documentary, a return to reality, a "true" representation of everyday life and a departure from staged photographs (a de facto rejection of late Stalinist Press photography). The second component of the debates focused on the form documentary photography was to take, in other words, how documentary reality was to be presented to viewers. This likewise included discussions of the purpose of photography, juxtaposing contemporary Soviet photojournalism not only with the vices of Western photography, but also with the formalist mistakes of the $1920 \mathrm{~s}$ and 193 os avant-garde. "Modern bourgeois photographers reduce the purpose of photographing to searching for extravagant camera angles and unusual lighting effects," wrote Volkov-Lannit. Yet, "Soviet photography does not ignore sharp angles...However, we do not pursue photographic properties as an end in themselves, which inevitably leads to distortion." 39 Volkov-Lannit reveals that the sharp angles, abstraction, and experimentation with perspective, points of view and lighting pursued by the avant-garde and bourgeois photographers were not at odds with modern Soviet photography. Rather, the pursuit of photography for aesthetics alone, i.e. digression into formalism (of which the Western and avant-garde photographers were guilty), was what made these images unacceptable. During the cultural Thaw, incorporating or exploring these technical and stylistic aspects in photography was not only acceptable, but actively encouraged by Sovetskoe foto, photography critics, and photographers themselves. As the history of the avant-garde was re-written by critics such as Morozov and Volkov-Lannit, elements of avant-garde photography resurfaced as a means of fulfilling the simultaneous requirements of index and artistry in Soviet photojournalism. Thus, while the general philosophy of the ROPF became the theoretical basis for 1950s and 196os photography, elements of Oktiabr's stylistic approach to photography also reemerged as standard practice in press photography.

In the months following the Secret Speech, and before the reestablishment of Sovetskoe foto, the journal Sovetskaia pechat (The Soviet Press) published

was vehemently opposed by both groups. "Po tvorcheskim gruppirovkam A. Rodchenko iskliuchen iz gruppa 'Oktiabr," Proletarskoe foto, no.3 (1932): 27; Boris Ignatovich, "Ob odnoi opasnoi tendentsii," Obsuzhdenie vystavki masterov sovetskogo fotoiskusstva $v 1935$ g., (Moskva: 1935): 1. Also see Aleksandr Rodchenko, "Master i kritika," Sovetskoe foto, no. 9 (1935): 4 .

Leonid Volkov-Lannit, O kompozitsii reportazhnogo fotoportreta, 19. 
a report about a photography exhibition at the Central House of Journalists. The author, photographer Y. Prigozhin, noted that at the exhibition's opening the photographers were largely critical. ${ }^{40}$ They were acutely aware of staging, an issue that had preoccupied photographers in the 1920 and $1930 \mathrm{~s}$ because it obscured the documentary nature of photography. ${ }^{41}$ Many commentators remained wary of staging in post-Stalinist photography, for either dramatic artistic or documentary purposes, because it "condemns and rejects the viewer, who is fond of the photo essay for what it realistically and accurately reproduces - the movement of life, of work..." This comment harkens back to the debates of the 1930s and would continue throughout the 1950s and 196 os. $^{42}$ This, however, did not prevent Prigozhin from commenting that on the whole, the images set a "visible example of true artistic reportage... and was accepted by the audience with a sincere appreciation." ${ }^{43}$ Prigozhin's article demonstrates that photographers continued to rehash debates about "truth" in the artistic and documentary features of photography made by photographers in the 1920 and 1930 .

The nature of the debate about artistic aspects in photography at the time correlated directly to the questions photographer artists and photographer journalists were asking in the 1920 and 1930s. Photography critiques in Sovetskoe foto demonstrate the very ambiguity faced by Soviet photographers in shooting artistic (or even journalistic) photographs: what constitutes too much abstraction, and what style or styles should a successful photograph incorporate? When it was reestablished, as when it was founded in 1926, Sovetskoe foto was intended to be a journal for photojournalists, not art photographers. ${ }^{44}$ This was clearly stated in an article published in the first issue of the journal in 1926 (as well as on the back cover), and was reiterated in the first issue of $1957 .^{45}$ Some photographer-journalists who worked for the illustrated journal

40 Y. Prigozhin would later become a member of the editorial committee at Sovetskoe foto.

41 David Shneer, Through Soviet Jewish Eyes: Photography, War, Holocaust, (New Brunswick: Rutgers University Press, 2011), 55 .

Y. Prigozhin, "Vetv' zhurnalistiki; zametki o fotoreportazhe," Sovetskaia pechat, no. 5 (1956): $5^{0 .}$

43 Ibid, 49.

44 "Artisanal professionals are confined to narrow circles of fine photo-artists that...are active and lively, but...disorganized" and thus needed guidance from a journal devoted to photojournalism. "The "magazine's main strength is the assistance of a wide range of photo enthusiasts and photo-reporters, who, for a long time, have waited for assistance, and who will take counsel from and befriend a Soviet photo-journal." Sovetskoe foto, no. 1 (1926): 1 .

45 Portions of the aforementioned article were republished in the first 1957 issue. Ibid, 1. 
supported the idea that too much criticism "drowns out the photo journalistic principle" of devotion to documentation. ${ }^{46}$ But many disagreed with this point of view, and one (unnamed) photojournalist for Ogonek (Little Flame) stated that there was no reason that "photo art" and "photo reportage" should be mutually exclusive, as there were many examples where "art and reportage were combined in single photographs." ${ }^{.77}$ This was repeated in nearly every issue of Sovetskoe foto, including photographer Lydia Dyko's (kandidat iskussnvovedeniia) 1959 article about the Twenty First Party Congress's program, which stated that "photographers, publicists, documentalists (dokumental'isty), professional and amateur photographers act like artists in the fullest and the highest sense of the words" through helping soviet citizens "aesthetically comprehend reality."48 In the hands of photographers, "the camera turns into a delicate instrument that visualizes the brightest, most vivid, and the most valuable features of reality, transforming them into the artist's reflections on current events and phenomena." ${ }^{\text {99 }}$ Thus, the artistic value of the image derived not only from the photographers' vision, but also from the camera's ability to document reality.

Aesthetics, as discussed in the 1950 s and 196os, were thus informed by a number of factors in dialogue with past questions posed by avant-garde photographers as well as present questions about the form and content of photojournalist's images. In terms of appraising the quality of photographic work, critics often compared visual arts to other genres such as literature. Discussions about aesthetics in Sovetskoe foto made almost no effort to problematize the "reality" portrayed in photographs. Taking photography as a technology that could be harnessed for the purposes of propagating state projects, neither the Ministry of Culture nor the Union of Journalists appeared to have any interest in the deceptive qualities of photography. Despite very real concerns about avoiding purely documentary photographs, those that were quickly and shoddily shot, and "naturalism," (an amorphous category used to describe "bad" photographs), critics lacked any real language with which to appraise photographs, especially those that straddled the line between art object and indexical document. ${ }^{50}$

46 V.T. Stigneev, Vek Fotografii, 221.

47 'Uspeshno reshat' glavnie temi fotopublitsistiki seminar fotokorrespondentov belorussii, latvii, litvii, estonii," Sovetskoe foto, no. 8 (1961): 21.

48 Lydia Dyko, "Byt' dostoinymi epokhi," Sovetskoe foto, no. 4 (1959): 2.

49 Ibid, 3.

50 In 1935 Leonid Mezhericher described naturalist photography as a problem associated with novice photographers who show "random details" in their photographs, portraying the "unimportant details" as "important." L. Mezhericher, “Tvorcheskie problem fotografii,” 
Keeping in mind the necessary artistic and documentary requirements for Soviet photographs, particularly in photojournalism, as well as the weight placed on creative and expressive images, it is perhaps no surprise that unique angles, points of shooting and close cropping reemerged in press photography. Though photographers in the 1950s and 196os were exploring these avant-garde techniques, their work was by no means as adventurous as the work of 1920 artists who were experimenting with far more abstracted images and severe cropping. Critics were able to agree on certain principles that applied specifically to photography. In the early 196os, Sovetskoe foto again began discussing the nature of press photography as it related to art. Soviet press photography should provide an eyewitness account, the focus of previous decades, but creativity was of equal importance to photojournalists, a

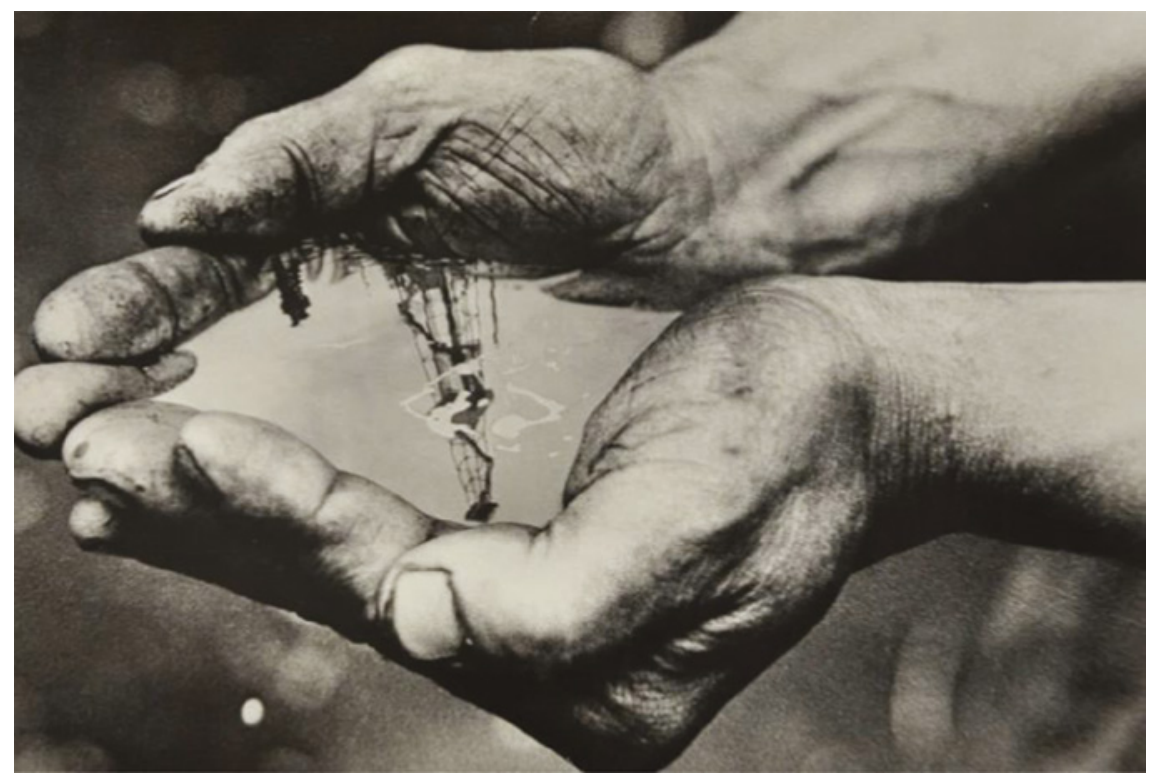

FIgure 1 Aleksandr Ptitsyn, Neft' Sibiri, black-and-white photograph, 1962.

Sovetskoe foto, no. 1 (1935): 4. The following year, V. Grishanin wrote that naturalism was characterized by "neglecting artistic form," presenting "bare information with indifference to the ideological meaning of the picture" and that such photographers were guilty of "generalizations and accidental exclusion of facts." These descriptions are not necessarily at odds with one another, but certainly leave the category of naturalism open to interpretation. Grishanin's definition of naturalism was also virtually indistinguishable from his description of formalism which "selects and displays random sections of reality," "ignores the ideological content of phenomena" and "neglects the audience of the artist." V. Grishanin, "Spetsifika fotoiskusstva," Sovetskoe foto, no. 7 (1936): 15. 
departure from Stalinist photography which was described as "unoriginal."51 Articles in Sovetskoe foto transitioned from discussing photography as distinctively documentary with artistic aspects, to arguing that photojournalism itself was artistic. In March 1962, Sovetskoe foto published a three page article about Alexander Ptitsyn, photojournalist at the journal Sovetskii soiuz (The Soviet Union), and his exhibition at the Central House of Journalists. The author, E. Kravchuk, describes Ptitsyn's work as "fresh, bright, with impressive form." As a photographer, Kravchuk wrote, Ptitsyn possessed "acute observation, the vision of the artist." ${ }^{2}$ Kravchuk goes on to say that Ptitsyn's work typifies modern photojournalism in that his "compositions are characterized by dynamism." In addition to the informational value of the images they held the "quality of a work of art..." ${ }^{53}$ Yet Ptitsyn's documentary images, such as Neft' sibiri, are evocative of avant-garde montage. The oil rig reflected in the hands of the worker is fragmented and appears unnaturally pasted into the image (Figure 1). For critics, however, these features of his style were not an impediment to his documentary work, instead adding to the "dynamism" of his images. "A. Ptitsyn," Kravchuk wrote, "is a photojournalist and from the beginning...his work is distinguished by ideology, depth of thought, originality of interpretations, temperament, and perfect pictorial form." ${ }^{54}$ Kravchuk draws the reader's attention to Ptitsyn as journalist, but also towards his creative process, and concretely highlights the connection between photojournalism and aesthetics.

Prominent Soviet photojournalists were also discussing questions of socialist realism in relation to this new style of photography. In 1961 at a congress for photojournalists, Ogonek photo correspondent Vsevolod Tarasevich stated that in terms of photographic style "there is only one creative method, that of socialist realism. Reporting is one of the most effective means though which this method is carried out in the photograph." ${ }^{55}$ Interestingly, however, as a photojournalist Tarasevich was heavily reliant on avant-garde shooting angles and cropping in his images, which in late-Stalinist photography proved antithetical to socialist realism. His 1958 photographs Telematchta and $\mathrm{Na}$ promyshlennoi vystavke, are reminiscent of Aleksandr Rodchenko's industrial photography from the late 1920s, obscuring the subject of the image and shot from below as if the viewer is embedded in the steel webbing or mechanisms of the machinery (Figures 2-4).

\footnotetext{
51 Semyon Friedland, “Tvorcheskii 'klimat' v redaksii," Sovetskoe foto, no. 8 (1961): 23.

$5^{2} \quad$ E. Kravchuk, Sovetskoe foto, no. 3 (1962): 25 .

53 Ibid, 25 .

54 Ibid, 25 .

55 'Uspeshno reshat' glavnie temi fotopublitsistiki seminar fotokorrespondentov belorussii, latvii, litvii, estonii," 20.
} 


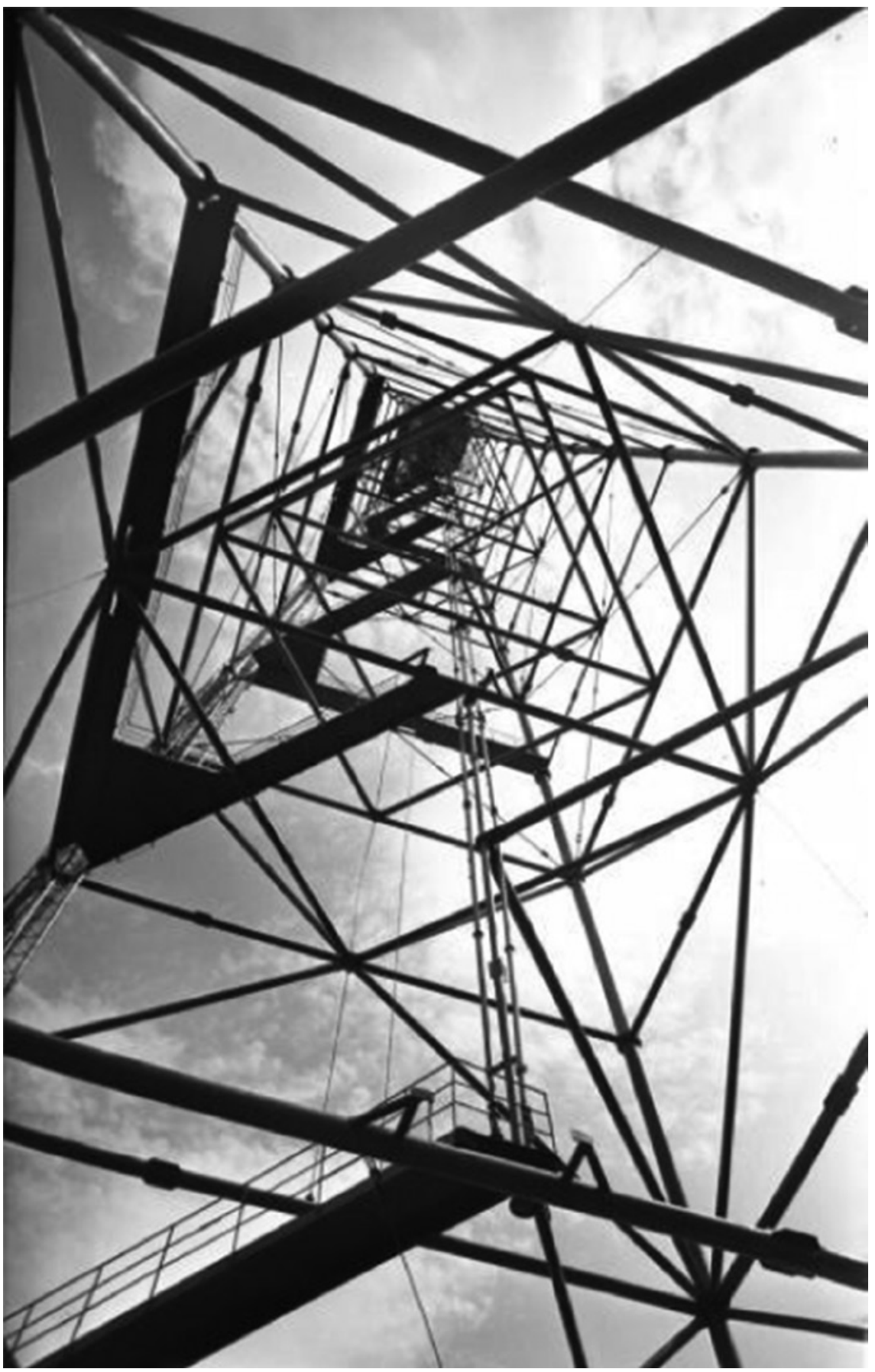

FIGURE 2 Vsevolod Tarasevich, Telematchta, black-and-white photograph, 1958. 


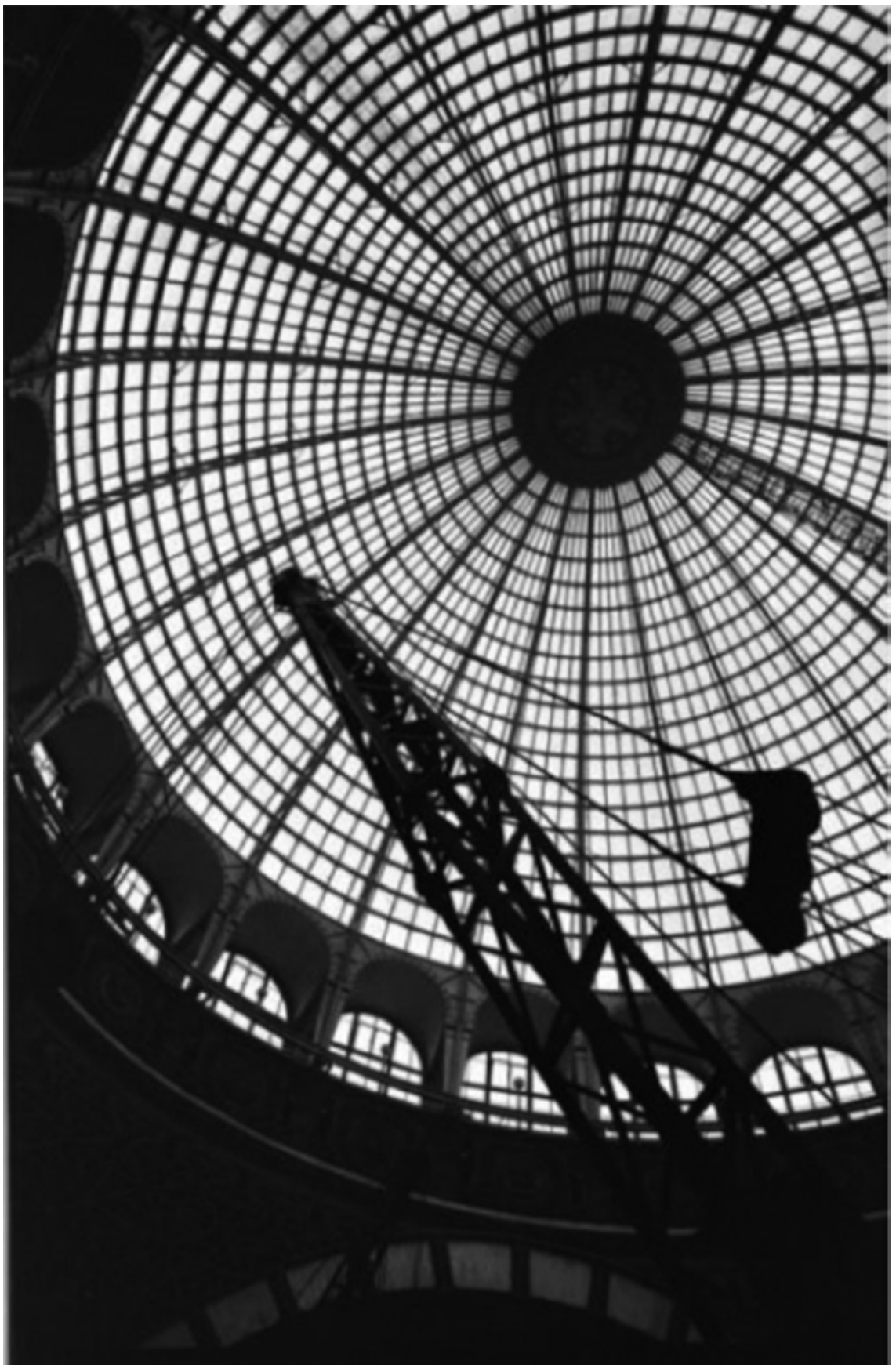

FIGURE 3 Vsevolod Tarasevich, Na promyshlennoi vystavke, black-and-white photograph, 1958. 


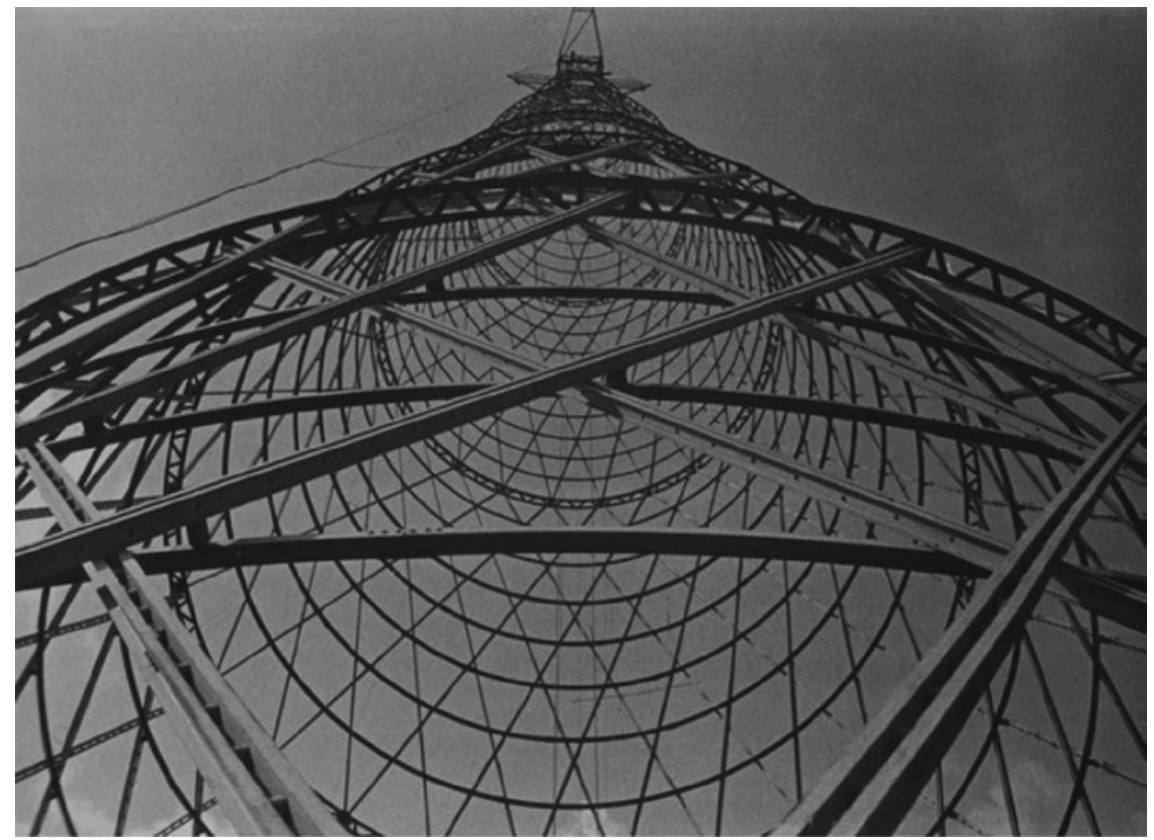

FIGURE 4 Aleskandr Rodchenko, Shukhovskaya bashnia, black-and-white photograph, 1929.

CriticVolkov-Lannit approved of these developments in his appraisal of contemporary press photography, explaining that photographers should not be afraid to "approach light and shadow in non-traditional ways" in order to literally show the subject in a different light. ${ }^{56}$ The author states that "if nothing else, it is a conscious effort on the part of the photographer to organize an expressive frame." 57 He explains that "sharp angles and unusual proportions are sometimes more appropriate" even if it means excessive attention to detail. ${ }^{58}$ Photographers agreed. Antonin Gribovsky's 1962 photograph, Net voiny, replicates the effect of Rodchenko's 1925 photographs from the series Dom na Miasnitskoi. Gribovsky's 1962 photograph, like the buildings in Rodchenko's series, is shot from almost precisely the same angle, looking up at what appears to be the side of a factory building (Figures $5^{-6}$ ). These two photographs are undeniably similar. Shooting photographs from non-traditional vantage points, especially from below, was a feature replicated in numerous photographs in Sovetskoe foto. Mikhail

\footnotetext{
$56 \quad$ L. Volkov-Lannit, "O kompozitsii fotoreportera," Sovetskoe foto, no. 5 (1962): 25.

57 Ibid, 25.

58 Ibid, 25 .
} 


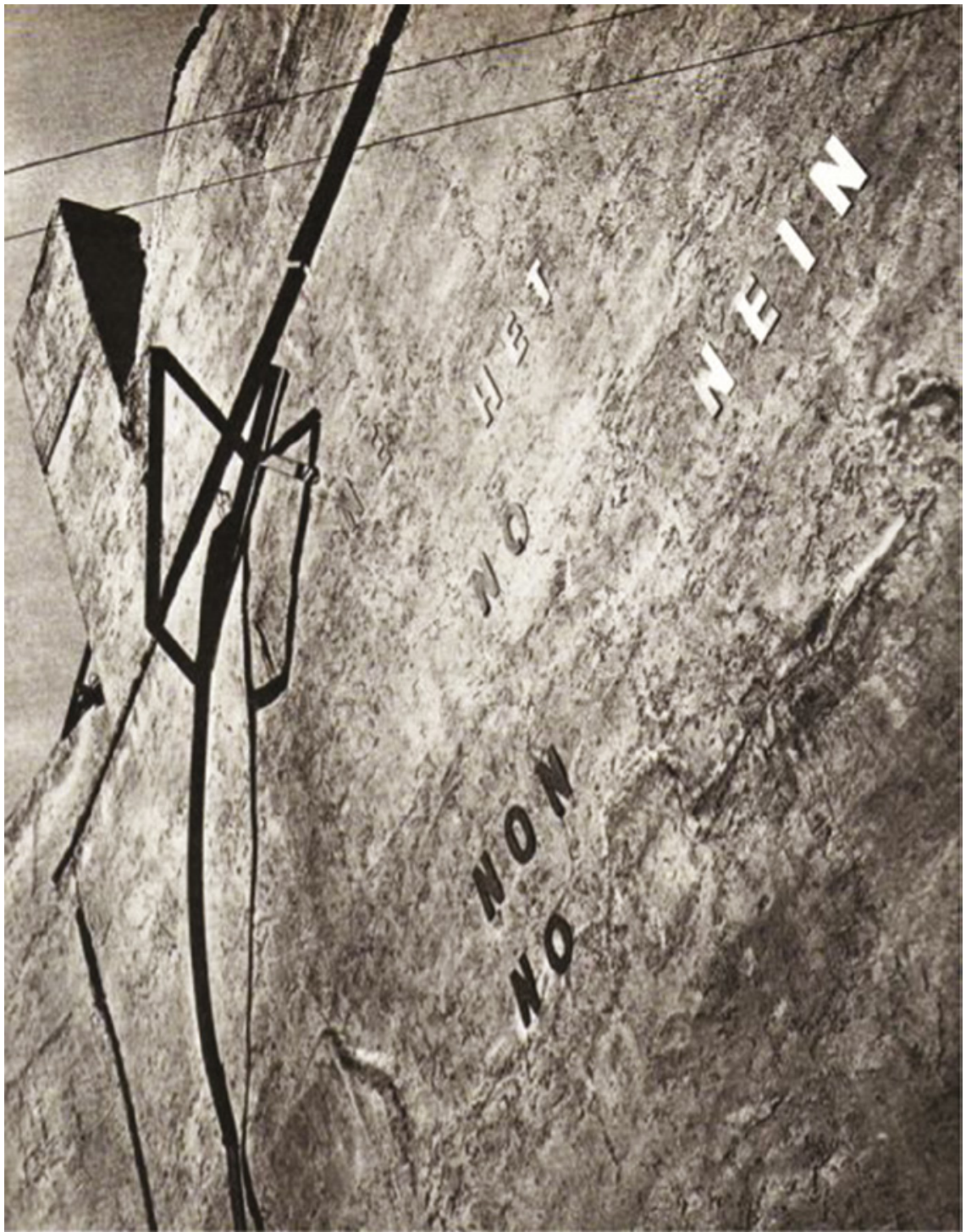

FIGURE 5 Antonin Gribovsky, Net voiny, black-and-white photograph, Sovetskoe foto, no. 3 (March 1962).

Kliuev's 1959 image Stroitel', is undoubtedly similar to Boris Ignatovich's 1929 photograph Na stroike not only in title but in content (Figures 7-8). Heavily linear in both compositions, beams cross the frame of the photographs. The respective photographers view their subjects (both the builder and the 


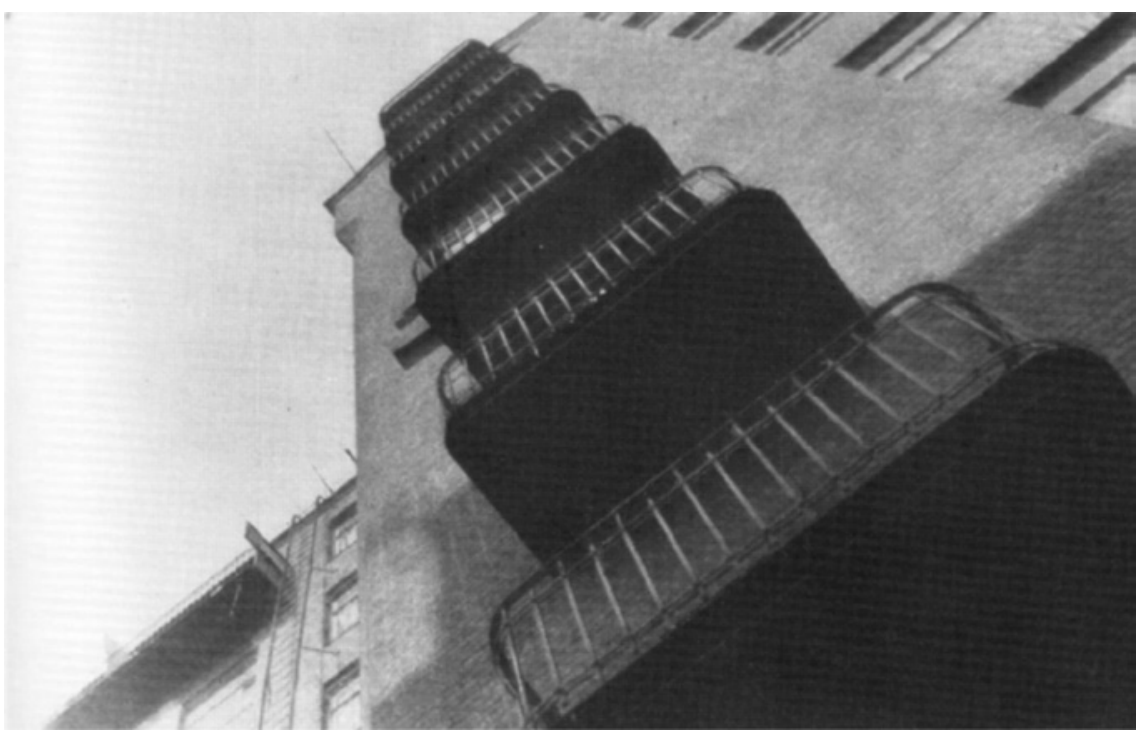

FIGURE 6 Aleksandr Rodechnko, from series Dom na Miasnitskoi, black-and-white photograph, 1925.

building) from below, emphasizing the upward constructive movement of both. Both images do not reveal much about the builders' features, and both rely heavily on light (the sky) contrasting with the project itself (in shadow but approaching the light). A. Bazhenov's photograph Plotniki published in the February 1959 issue of Sovetskoe foto, shares not only subject of the aforementioned photographs, but likewise replicates the style and linear construction of the image (Figure 9).

The particular political climate of the cultural Thaw allowed photographers the possibility of investigating avant-garde aesthetics. The influence of the avant-garde on photographers in the 1950s and 1960s is easily identifiable and cannot be underestimated. Photojournalists in the late 1950s and early 1960s adopted this photographic style implicitly, without explicitly stating the avantgarde as an inspiration, instead drawing attention once again to the indexical features of the images in addition to their artistry. Photographs that drew on avant-garde techniques became a template of sorts for many photographers in the late 1950s, and the return of photographs using the same de-framing methods, unique angles, and experimentation with light is significant in that their reemergence was heralded as the proverbial breath of fresh air that press photography required. This was likewise accompanied by revisionist critiques of avant-garde artists' work, rehabilitating avant-garde stylistic choices. A steady 


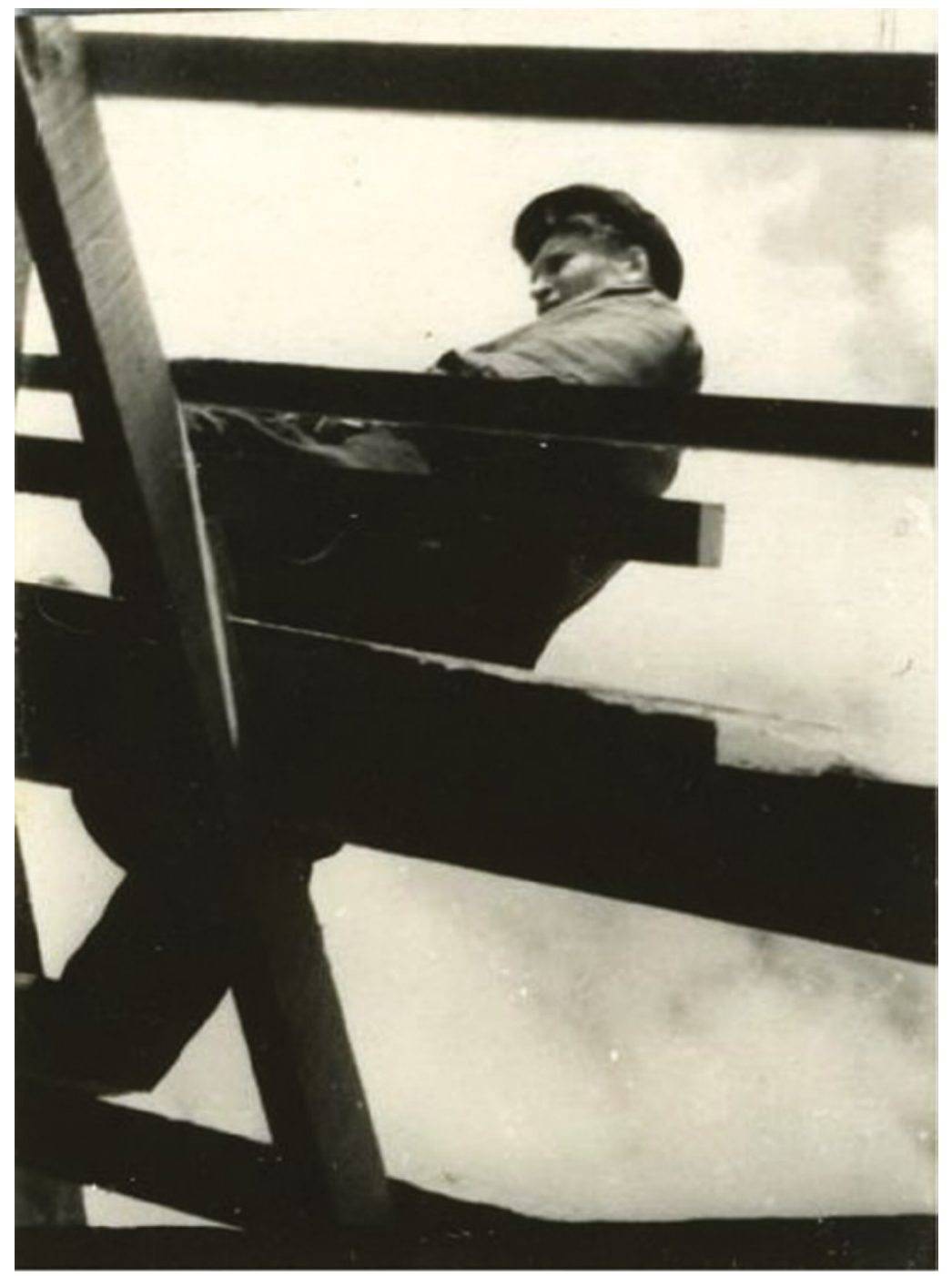

FIGURE 7 Mikhail Kliuev, Stroitel, black-and-white photograph, 1959.

stream of articles about Rodchenko and his photographs had appeared in Sovetskoe foto after $1957 .{ }^{59}$ In 1961, Sovetskoe foto published a four-page article on Rodchenko. Volkov-Lannit, the author of the piece, explained that "the role

59 The first of these appeared in June 1957. I. Svistunov, 'Raboty A.M. Rodchenko,' Sovetskoe foto, no. 6 (1957): 72-73. 


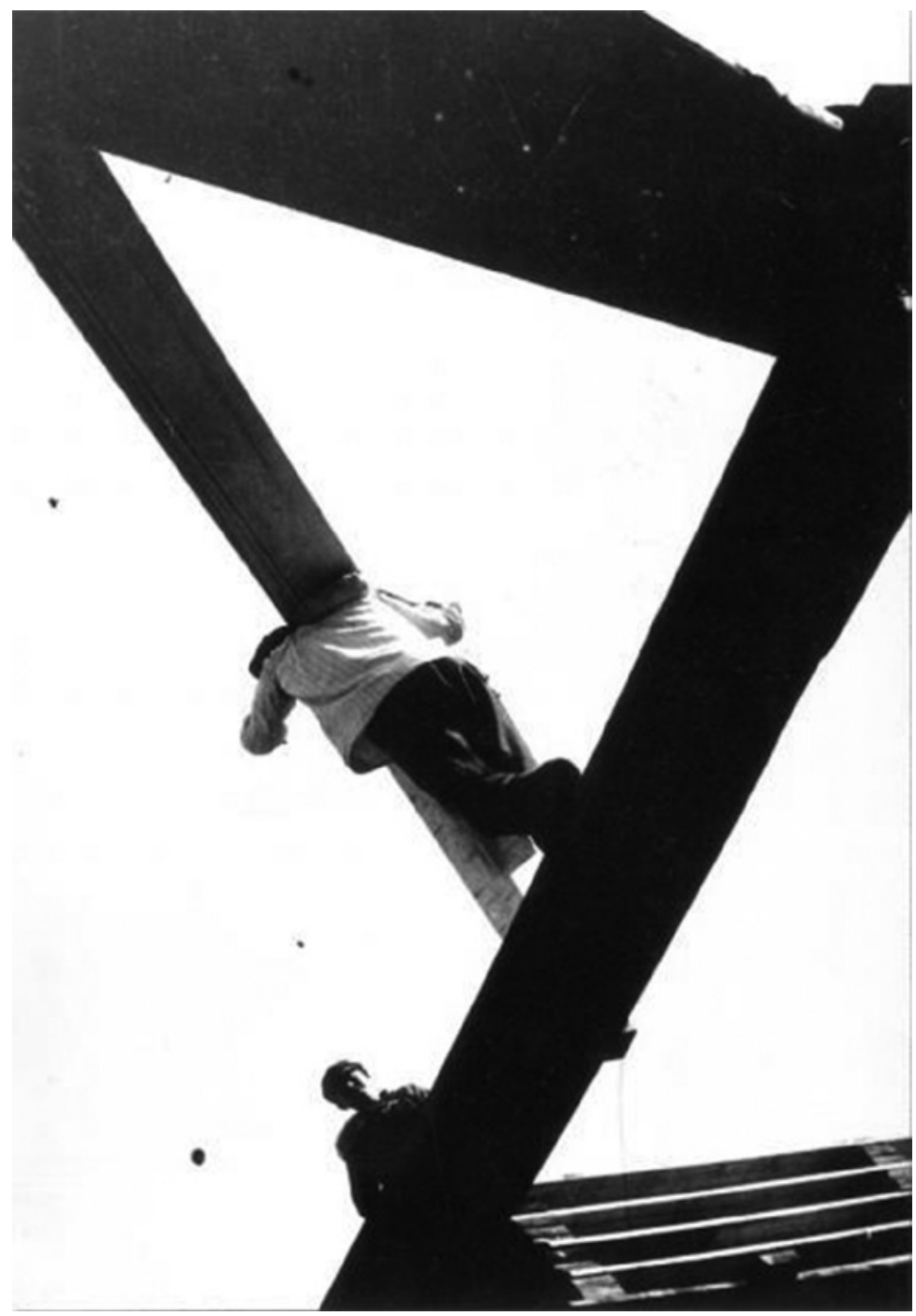

FIGURE 8 Boris Ignatovich, Na stroike, black-and-white photograph, 1929.

of Rodchenko in photography was equal to the role of Mayakovsky in poetry."60 Volkov-Lannit went on to explain that during the 1930s "charges of formalism, at times, reached the point of irrationality... Rodchenko, certainly, was not the militant formalist that some super conformists wished."61 Volkov-Lannit's

\footnotetext{
6 L. Volkov-Lannit, "Aleksandr Rodchenko," Sovetskoe foto, no. 12 (1961): 20.

61 Ibid, 21.
} 


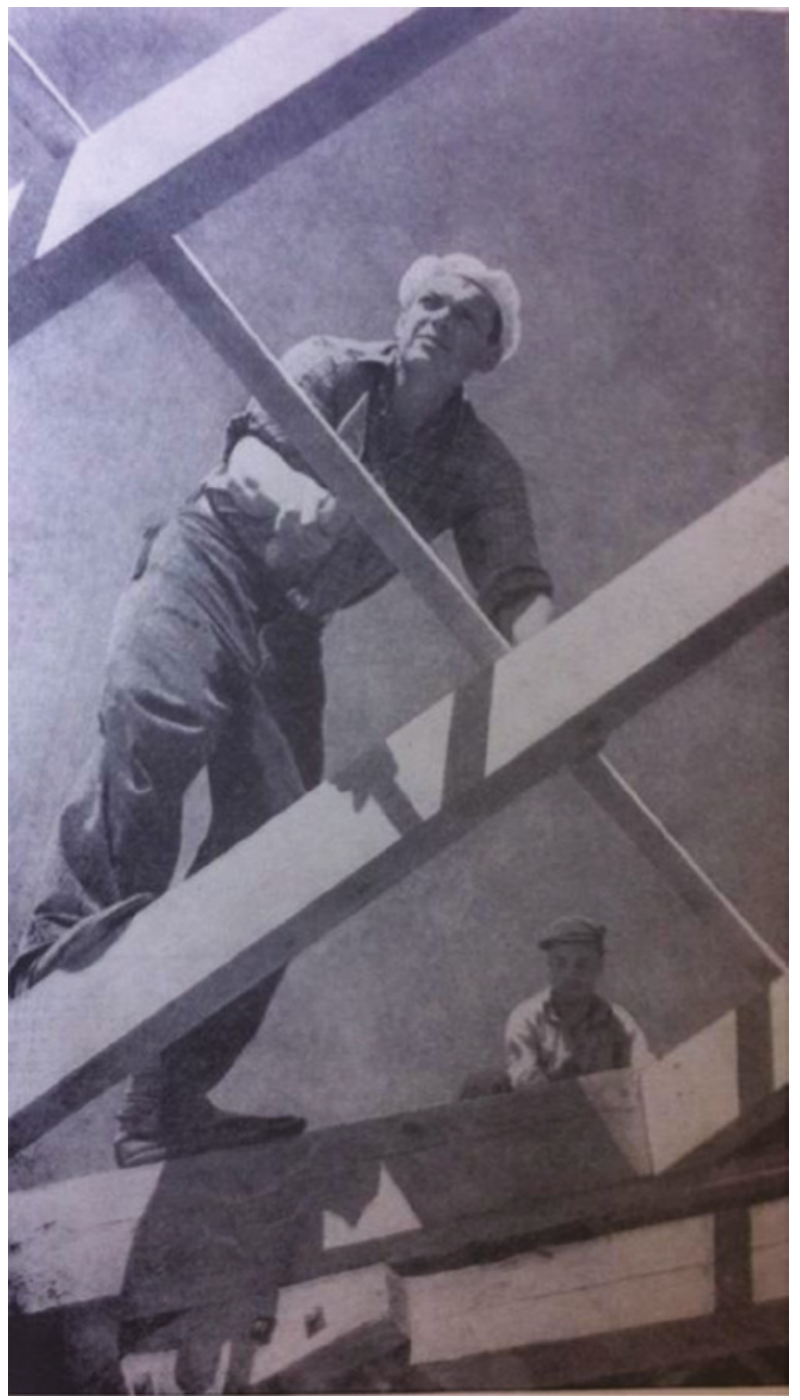

FIGURE 9 A. Bazhenov, Plotniki, black-and-white photograph, Sovetskoe foto, no. 2 (February 1959).

rehabilitation of Rodchenko's artwork is more or less in keeping with the cultural policies of the Thaw era. Two years earlier, Sovetskoe foto contributor Sergei Shimanskii made similar claims about Boris Ignatovich's work, particularly his $193^{\circ}$ photograph $U v k h o d a v$ Ermitazh, in which Shimanskii claimed that current press photography was hardly as "expressive" (byrazitel'nykh) as Ignatovich's image (Figure 10). The image conjures up "deep thoughts and arouses 


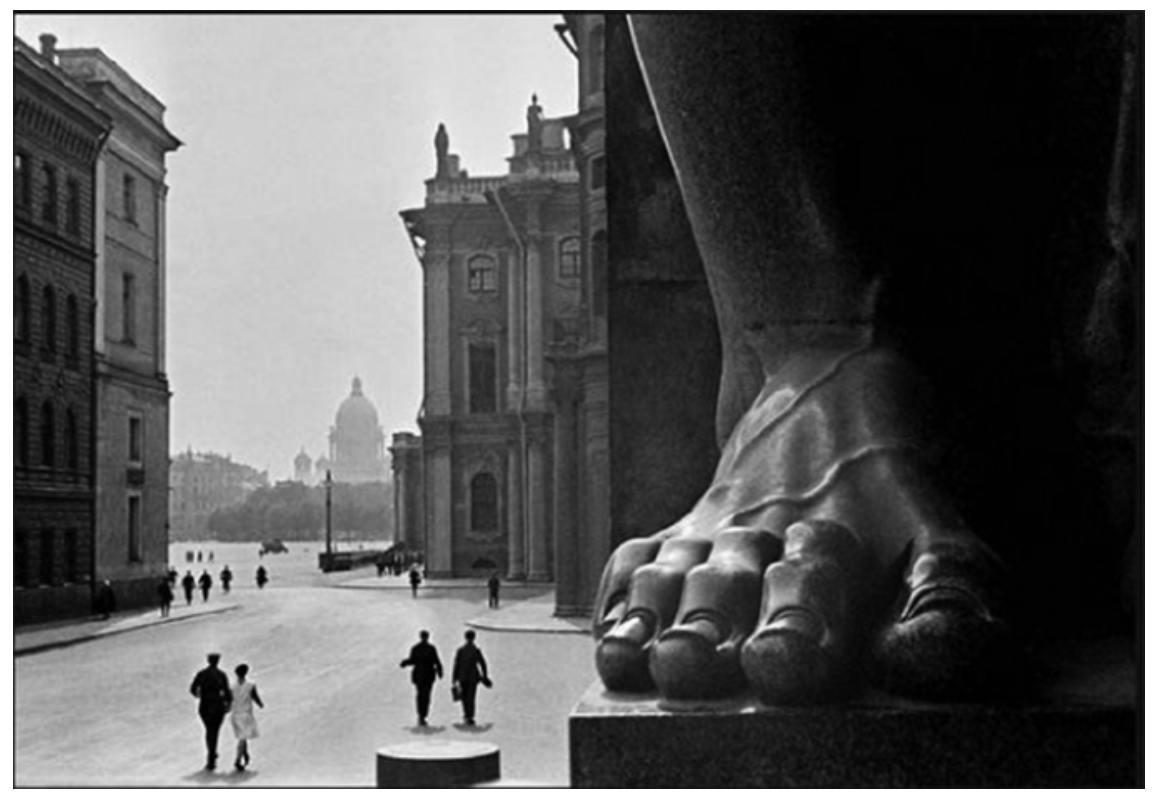

FIGURE 10 Boris Ignatovich, U vkhoda v Ermitazh, black-and-white photograph, 1930.

great feeling" demonstrating the "greatness in the minutia" of everyday. This posthumous revival of avant-garde images through their reappraisal thirty years later contributed to the normalization of contemporary stylistic choices. The January 1959 issue of Sovetskoe foto even included a lengthy article by Valerii Gende-Rote demonstrating how one could achieve the desired cropping technique (Figure 11). ${ }^{62}$

Other contributors to Sovetskoe foto followed suit in rewriting the history of the avant-garde in relation to contemporary photography. Semyon Kirsanov's 1962 article "Art of the Future" attacked late-Stalinist photography, explaining not only was the avant-garde "unprecedented in artistic culture," but that Stalin's Cult of personality depended on images of pompous ceremonies, eclectic forms, especially in architecture, in painting, and in the field of material and consumer culture." 63 Openly denouncing the defamation of avant-garde work is not akin to admiring it as a relic of a bygone age. It was questioning the entire genre of art that the Cult of Personality perpetuated, including photography. Perhaps there were times when photographs were "temporarily cluttered by

62 Valerii Gende-Rote, “Kadrirovanie i kompozitsiia," Sovetskoe foto, no. 1 (1959): 33-41.

63 Semyon Kirsanov, "Iskusstvo budushchego", Sovetskoe foto, no. 7 (1962): 25. 

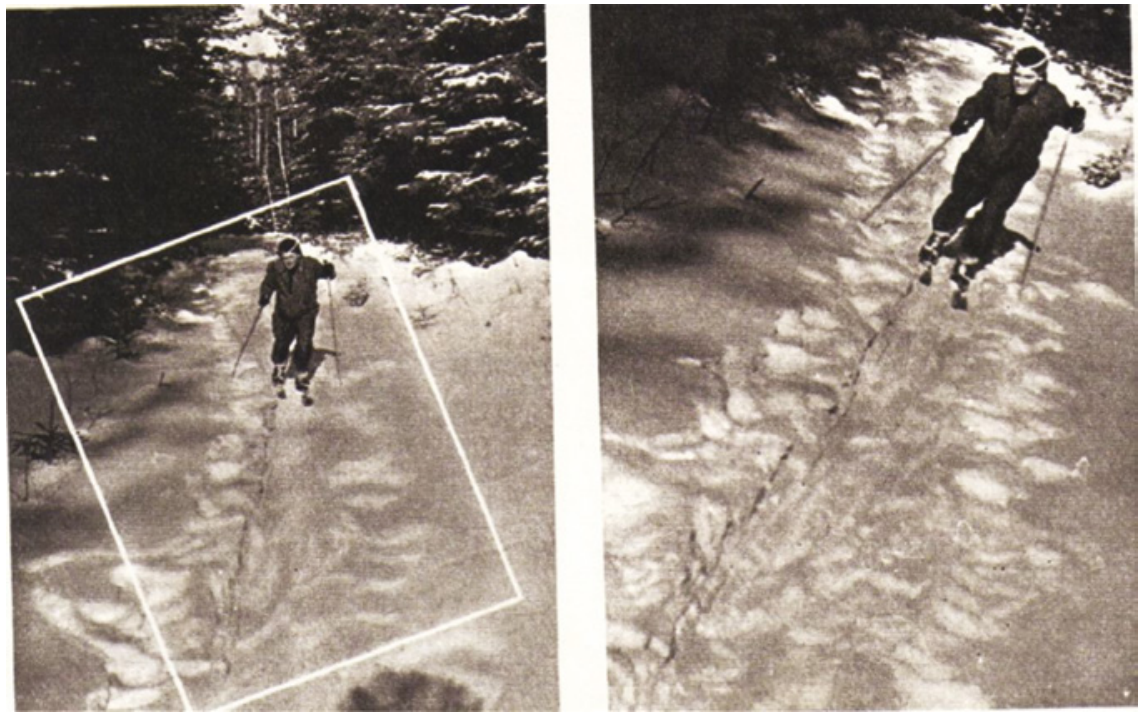

FIGURE 11 E. Volkov, Na lyzhne, black-and-white photographs, Sovetskoe foto, no. 1 (January 1959)

formalistic bad taste," yet this was hardly as damaging to the genre as the stoic and uninteresting images produced during the late Stalinist period. ${ }^{64}$

The prevalence and praise of images clearly influenced by avant-garde photographers, and Rodchenko and Ignatovich in particular, demonstrates that far from putting a decisive end to discussions of avant-garde aesthetics of the 1920s, Stalinist consolidation, and then suppression, of avant-garde photographic styles may have truncated debates in the mid-1930s, but it certainly did not permanently conclude these debates. Rather, the cultural Thaw offered photographers an opportunity to reinvestigate, reincorporate, and normalize avant-garde photography. While articles in the premier photography journal Sovetskoe foto heralded photography as a new art form, critics and theorists were hesitant to describe photography as "high art," but found photography to be an artistic, socialist realist medium based on the creative aspirations of photographers and the documentary properties of photography itself. The manifestation of the documentary and artistic aspects of photography were visualized through reappropriating avant-garde techniques, which disappeared from press photography in the late Stalinist period. This corresponded with rewriting the histories of the avant-garde and a reappraisal of avant-garde

64 Ibid, 25 . 
photography, reestablishing heavy cropping and angular compositions in press photography. The combined effects of these developments ultimately de-Stalinized photojournalism, not only in the way images looked, but also the ways in which photography was discussed.

The effects of the cultural Thaw allowed photographers the opportunity to push the boundaries of acceptable visual representation, incorporating modernist styles and influences that had been discredited in earlier decades. During this period, photojournalists, as well as editors and contributors to Sovetskoe foto reinvestigated the legacy of the avant-garde, colloquializing unique points of shooting, and angular cropping. Though unable to convince cultural authorities of the artistic nature of photography, the reinvestigation of avant-garde aesthetics in the 1950 and 1960 s contributed to the standardization and normalization of avant-garde photography in the late Soviet period.

\section{Works Cited}

Baltermants, Dmitri. Fotografia, no. 2 (1972): 19.

Bendavid-Val, Leah. Propaganda and Dreams: Photographing the 193os in the USSR and the Us. Zurich; Edition Stemmle, 1999.

Bittner, Stephen V. The Many Lives of Khrushchev's Thaw: Experience and Memory in Moscow's Arbat. Ithica: Cornell University Press, 2008.

Brik, O. "Foto-kadr protiv kartiny." Sovetskoe foto, no. 2 (1926): 40-42.

Bugayeva, M. “O printsipi partiinost' v fotoiskusstva." Sovetskoe foto, no. 2 (1961): 1-2.

Chlenova, Masha. On Display: Transformations of the Avant-Garde in Soviet Public Culture, 1928-1933, PhD diss. Columbia University, 2010.

Dickerman, Leah. "Camera Obscura: Socialist Realism in the Shadow of Photography." October 93, no. 3 (2000): 138-153.

"Dlia verkhovnogo ideologicheskoi fotozhurnalistiki." Sovetskoe foto, no. 3 (1961): 1.

Dobrenko, Evgeny. Political Economy of Socialist Realism. New Haven: Yale University Press, 2007.

Dobson, Miriam. Khrushchev's Cold Summer: Gulag Returnees, Crime, and the Fate of Reform After Stalin. Ithica: Cornell University Press, 2011.

Dyko, Lydia. "Byt' dostoinymi epokhi." Sovetskoe foto, no. 4 (1959): 1-3.

Evgenov, S. "Po stranitsam Sovetskoe foto: Ranie snimki 1926-1928." Sovetskoe foto, no. 4 (1941): 9-13.

Filipov, L. "Rodilsia v oktiabre." Sovetskoe foto, no. 11 (1964): 1-2.

Friedland, Semyon. "Tvorcheskii 'klimat' v redaksii." Sovetskoe foto, no. 8 (1961): 22-3.

Gende-Rote, Valerii. "Kadrirovanie i kompozitsiia." Sovetskoe foto, no. 1 (1959): 33-41. 
Grishanin, V. "Spetsifika fotoiskusstva." Sovetskoe foto, no. 7 (1936): 15.

Ignatovich, Boris. "Ob odnoi opasnoi tendentsii." Obsuzhdenie vystavki masterov sovetskogo fotoiskusstva $v 1935$ g., Moskva: 1935.

Jones, Polly ed. The Dilemmas of De-Stalinization: Negotiating Cultural and Social Change in the Khrushchev Era. London: Routledge, 2006.

Jones, Polly. Review of 'Khrushchevskaia ottepel' i obshchestvennye nastroeniia $v$ sssR $v$ 1953-1964 gg. and Kak eto delalos' $v$ Leningrade: Tsenzura $v$ gody ottepeli, zastoia $i$ perestroika, 1953-1991," Kritika 8, no. 3 (2007), 695-704.

Jones, Polly. "The Personal and the Political: Opposition to the Thaw and the Politics of Literary Identity in the 1950s and 1960s." The Thaw: Soviet Society and Culture During the 1950s and 196os, eds. Denis Kozlov and Eleonory Gilburd 231-265. University of Toronto Press: Toronto, 2013.

Kagin, M. “Soderzhanie i forma v proizvedeniiakh fotoiskusstva." Sovetskoe foto, no. 5 (1968): 25-7.

King, David. The Commissar Vanishes: The Falsification of Photographs and Art in Stalin's Russia. New York: Metropolitan Books, 1997.

Kravchuk, E. Sovetskoe foto, no. 3 (1962): 25-6.

Kirsanov, Semyon. "Iskusstvo budushchego." Sovetskoe foto, no. 7 (1962): 24-5.

"Mezhdunarodnie kommunikatsii fotoiskusstva." Sovetskoe foto, no. 12 (196o): 1.

Mezhericher, L. "Tvorcheskie problem fotografii." Sovetskoe foto, no. 1 (1935): 4-7.

Morozov, Sergei. Fotoilliustratsiia v gazete. Moskva: Goskinoizdat, 1939.

Morozov, Sergei. Sovetskaia khudozhestvennaya fotografiia. Moskva: Isskustvo, $195^{8}$.

"O ser'eznykh nedostatkakh v soderzhanii zhurnala Ogonek," 9 September 1958 (RGANI f. 11, op. 1, d. 20, l. 2).

“'Otosiudu' v fotosektsiiakh soiuza zhurnalistov," Sovetskoe foto, no. 7 (1961): 44.

"Po tvorcheskim gruppirovkam A. Rodchenko iskliuchen iz gruppa 'Oktiabr." Proletarskoe foto, no. 3 (1932): 27-8.

'Privetstvie TsK KPSS vsesoiuznomu s'ezdu sovetskikh khudozhnikov.' Sovetskoe foto, no. 3 (1957): 1-2.

Prigozhin, Y. “Vetv' zhurnalistiki; zametki o fotoreportazhe." Sovetskaia Pechat, no. 5 (1956): $5^{0 .}$

Reid, Susan E. "Photography in the Thaw." Art Journal 53, no. 2, (1994): 33-39.

Rodchenko, Aleksandr. "Master i kritika." Sovetskoe foto, no. 9 (1935): 4.

Shneer, David. Through Soviet Jewish Eyes: Photography, War, Holocaust. New Brunswick: Rutgers University Press, 2011.

Sovetskoe foto, no. 1 (1926): 1, Back Cover.

Sverdlovsk, V. “Vozmozhnosti v fotozhurnalistiki." Sovetskoe foto, no. 6 (1957): 14-15.

Stigneev, V.T. Vek Fotografii: Ocherki Ictorii Otechestvennoi Fotografii 1894-1994. Moskva: Knizhni Dom Lів воком, 2009.

I. Svistunov, 'Raboty A.M. Rodchenko,' Sovetskoe foto, no. 6 (1957): 72-73. 
Tupitsyn, Margarita. The Soviet Photograph 1924-1937. New Haven: Yale University Press, 1996.

"Uspeshno reshat' glavnie temi fotopublitsistiki seminar fotokorrespondentov belorussii, latvii, litvii, estonii." Sovetskoe foto, no. 8 (1961): 21-24.

Volkov-Lannit, L. "Aleksandr Rodchenko." Sovetskoe foto, no. 12 (1961): 20-1.

Volkov-Lannit, L. "O kompozitsii fotoreportera." Sovetskoe foto, no. 5 (1962): 24-5.

Volkov-Lannit, Leonid. O kompozitsii reportazhnogo fotoportreta. Moskva: Izdatelstvo Tsentral'nyi dom zhurnalista, 1962.

Zhukov, N. "Iz rabot, poctupivshikh na bystavku semiletka v deistvii 1962." Sovetskoe foto, no. 3 (1962): 3-5.

Zis', A. "C khudozhnika sprositsia." Sovetskoe foto, no. 8 (1960): 16-17.

Zubok, Vladislav. Zhivago's Children: The Last Russian Intelligentsia. Harvard University Press: Cambridge, MA, 2009.

\section{Secondary Literature and Suggested Reading}

Barron, Stephanie and Maurice Tuchman eds. The Avant-garde in Russia: New Perspectives 1910-1930. Cambridge, MA: MIT Press, 1980.

Groys, Boris. Art Power. Cambridge, MA: MIT Press, 2008.

Groys, Boris. The Total Art of Stalinism: Avant-Garde, Aesthetic Dictatorship and Beyond. Princeton: Princeton University Press, 1992.

Gorsuch, Anne E. and Diane P. Koenker eds. The Socialist 196os in Global Perspective. Indiana University Press; Bloomington, 2013.

Kozlov, Denis and Eleonory Gilburd. The Thaw: Soviet Society and Culture During the 1950s and 196os. Toronto: University of Toronto Press, 2013.

Neumaier, Diane ed. Beyond Memory: Soviet Non-conformist Photography and Photorelated Works of Art. New Brunswick: Rutgers University Press, 2004.

Rosenfeld, Alla and Norton T. Dodge eds Nonconformist Art: The Soviet Experience 19561986. London: Thames and Hudson, 1995.

Tupitsyn, Margarita. The Margins of Soviet Art: Socialist Realism to the Present. Milan: Giancarlo Politi Editore, 1989.

Wells, Liz ed. Photography: A Critical Introduction. $3^{\text {rd }}$ edition. New York: Routledge, 2004.

Wolfe, Thomas C. Governing Soviet Journalism: The Press and the Socialist Person After Stalin. Bloomington: Indiana University Press, 2005. 